\title{
Molecular phylogenetics, seed morphometrics, chromosome number evolution and systematics of European Elatine $L$. (Elatinaceae) species
}

\author{
Gábor Sramkó ${ }^{1,2}$, Attila Molnár V. \\ , János Pál Tóth ${ }^{3}$, Levente Laczkó \\ Horváth ${ }^{1}$, Lidia Skuza ${ }^{4}$, Balázs András Lukács ${ }^{5}$, Agnieszka Popiela ${ }^{6}$ \\ 1 Department of Botany, University of Debrecen, Debrecen, Hungary \\ 2 MTA-DE "Lendület" Evolutionary Phylogenomics Research Group, Debrecen, Hungary \\ 3 MTA-DE "Lendület" Behaviourial Ecology Research Group, University of Debrecen, Debrecen, Hungary \\ 4 Molecular Biology and Biotechnology Center, Department of Cell Biology, University of Szczecin, Szczecin, Poland \\ 5 MTA Centre for Ecological Research, Danube Research Institute, Department of Tisza Research, Debrecen, Hungary \\ 6 Department of Botany and Nature Conservation, University of Szczecin, Szczecin, Poland \\ Corresponding Author: Attila Molnár V. \\ Email address: mva@science.unideb.hu
}

Anna Kalinka ${ }^{4}$, Orsolya

The genus Elatine contains ca 25 species, all of which are small, herbaceous annuals distributed in ephemeral waters on both hemispheres. However, due a high degree of morphological variability (as a consequence of their amphibious life-style), the taxonomy of this genus remains controversial. Thus, to fill this gap in knowledge, we present the first detailed molecular phylogenetic study of this genus based on nuclear (rITS) and plastid ( $a c c D$-psal, psb)-petA, ycf6-psbM-trnD) sequences using 27 samples from 13 species. On the basis of this phylogenetic analysis, we provide a solid phylogenetic background for the modern taxonomy of the European members of the genus. Traditionally accepted sections of this tree(i.e. Crypta and Elatinella) were found to be monophyletic, only E. borchoni found to be a basal member of the genus - has to be excluded from the latter lineage to enforce monophyly. A number of taxonomic conclusions can also be drawn: $E$. hexandra, an high-ploid species is most likely a stabilised hybrid between the main sections; $\mathrm{E}$. campylosperma merits full species status based on both molecular and morphological evidence; $E$. gussonei is a more widespread and genetically diverse species with two main lineages, and; The presence of the Asian E. ambigua in the European flora is questionable. The main lineages recovered in this analysis are also supported by a number of synapomorphic morphological characters as well as uniform chromosome counts. Based on all the evidence presented here, two newsubsections within Elatinella are described: Subsection Hydropipera consisting of temperate species of the section, and; Subsection Macropodae including the Mediterranean species of the section. 
1 Molecular phylogenetics, seed morphometrics, chromosome number evolution 2 and systematics of European Elatine L. (Elatinaceae) species

3

4

\author{
Gábor Sramkóo ${ }^{1,2}$, Attila Molnár V. ${ }^{1}$, János Pál Tóth ${ }^{3}$, Levente Laczkó ${ }^{1}$, Anna Kalinka ${ }^{4}$, \\ Orsolya Horváth ${ }^{1}$, Lidia Skuza ${ }^{4}$, Balázs András Lukács ${ }^{5}$ \& Agnieszka Popiela ${ }^{6}$ \\ ${ }^{1}$ Department of Botany, University of Debrecen, Egyetem tér 1, H-4032 Debrecen, Hungary; \\ 2 MTA-DE 'Lendület' Evolutionary Phylogenomics Research Group, H-4032 Debrecen Egyetem \\ tér, Hungary; \\ ${ }^{3}$ MTA-DE 'Lendület' Behavioural Ecology Research Group, H-4032 Debrecen Egyetem tér, \\ Hungary; \\ ${ }^{4}$ Department of Cell Biology, Molecular Biology and Biotechnology Center, Faculty of Biology, \\ University of Szczecin, Waska 13, 71-415 Szczecin, Poland; \\ ${ }^{5}$ Department of Tisza Research, MTA Center for Ecological Research, H-4032 Debrecen, \\ Hungary; \\ ${ }^{6}$ Department of Botany and Nature Conservation, University of Szczecin, Felczaka 3c,71-412 \\ Szczecin, Poland
}

Running title: Systematics of European Elatine

\begin{abstract}
The genus Elatine contains $c a 25$ species, all of which are small, herbaceous annuals distributed in ephemeral waters on both hemispheres. However, due a high degree of morphological variability (as a consequence of their amphibious life-style), the taxonomy of this genus remains controversial. Thus, to fill this gap in knowledge, we present a detailed molecular phylogenetic study of this genus based on nuclear (rITS) and plastid (accD-psaI, psbJ-petA, $y c f 6-p s b M-t r n D$ ) sequences using 27 samples from 13 species. On the basis of this phylogenetic analysis, we provide a solid phylogenetic background for the modern taxonomy of the European members of the genus. Traditionally accepted sections of this tree (i.e. Crypta and Elatinella) were found to be monophyletic, only E. brochonii - found to be a basal member of the genus has to be excluded from the latter lineage to enforce monophyly. A number of taxonomic conclusions can also be drawn: E. hexandra, an high-ploid species is most likely a stabilised hybrid between the main sections; E. campylosperma merits full species status based on both molecular and morphological evidence; E. gussone $i$ is a more widespread and genetically diverse species with two main lineages, and the presence of the Asian E. ambigua in the European flora is questionable. The main lineages recovered in this analysis are also supported by a number of synapomorphic morphological characters as well as uniform chromosome counts. Based on all the evidence presented here, two new subsections within Elatinella are described: Subsection Hydropipera consisting of temperate species of the section, and; Subsection Macropodae including the Mediterranean species of the section.
\end{abstract}

\title{
INTRODUCTION
}

The waterworts (genus Elatine L.; Elatinaceae, Malpighiales) are small, ephemeral, aquatic herbaceous annuals, or short-lived perennials, inhabiting the muddy surfaces of ephemeral waters (e.g. temporary pools, shores of lakes and ponds, marshes, and rice-fields). These plants have an interrupted, but cosmopolitan distribution, showing strong preference for temperate 
47 regions in middle and high latitudes as well tropical mountain ranges (e.g. the Andes). The small, 48 inconspicuous, and mostly cleistogamous flowers of waterworts are usually self-pollinating, but outcrossing can also take place (i.e. facultative autogamy). Since no recent monograph exists for this genus, the total number of species is thought to be between $c a 10$ (Kubitzki, 2014) to $c a 25$ (Tucker, 1986). Most of the species is found in Europe, where ten species is registered (Uotila, 2009b) although Flora Europaea lists only eight species (Cook, 1968). Another center of the genus is in North America, where nine species are present (Tucker, 1986).

Surprisingly little work has been completed recently in the taxonomy of Elatine. The most recent worldwide monograph (Niedenzu, 1925) echoes the earlier work of Seubert (1845), and although Moesz (1908) proposed a slightly different classification, the original iteration is still used for the taxonomy of this genus. According to this classification, the genus can be split into two subgenera, Potamopytis (Adanson) Seub. which is represented just by the morphologically distinct (leaves in whorls) species Elatine alsinastrum L., and subgenus Elatine Seub. (subg. Hydropiper Moesz) which contains all the other species (leaves arranged opposite). The Elatine subgenus is further divided into two sections, Elatinella Seub. Which includes species with diplostemonous flowers (i.e. stamens arranged in two whorls and thus having double the number of sepals), usually arranged in a tetramerous flower, and Crypta (Nutt.) Seub. which includes species of trimerous flowers that show haplostemony (i.e. an arrangement of stamens in a single whorl opposite the sepals thus having an equal number of anthers and sepals). While Europe is rich in species belonging to section Elatinella (all species included in this section are native to Europe and temperate Asia with the exception of the North American E. californica A. Gray and South American E. ecuadoriensis Molau), section Crypta has a center of species diversity in North America, while Eurasia boasts just two species, E. ambigua Wight and E. triandra Schkuhr. The species of waterworts that occur in the Southern Hemisphere are all members of the latter section, with the exception of E. ecuadoriensis. The work presented in this paper focuses on European species but also provides an outlook on the North American members of the genus.

Although recent work has augmented our knowledge of the biology of European Elatine (Popiela and Łysko, 2010; Popiela \& al., 2011; Popiela \& al., 2012; Molnár V. \& al., 2013b; Popiela \& al., 2013; Takács \& al., 2013; Kalinka \& al., 2014), there are still few studies that deal with this taxonomy of this genus in Europe (Mifsud, 2006; Uotila, 2009c; Molnár V. \& al., 2013a). In the meantime, many new species have been described from the Americas and Australia (Mason, 1956; Schmidt-Mumm and Bernal, 1995; Albrecht, 2002; Garneau, 2006; Lægaard, 2008). Most researchers agree that seed morphology is of exceptional importance in the taxonomy of Elatine (Moesz, 1908; Mason, 1956; Cook, 1968; Mifsud, 2006; Molnár V. \& al., 2013a, Molnár V. \& al., 2015), and seed shape (i.e. how much it is curved) as well as seed surface reticulation (i.e. number and shape of seed pits) have traditionally been characters of high significance used for recognising species in the genus (Moesz, 1908; Tucker, 1986; Mifsud, 2006; Molnár V. \& al., 2013a). Although vegetative characters, including pedicel length and leaf-shape, are also sometimes emphasised as important sources of taxonomic information (Seubert, 1845; Niedenzu, 1925), these features have generally been thought to be more variable between aquatic and terrestrial forms of the same species than between separate species (Mason, 1956; Molnár V. \& al., 2013a; Molnár V. \& al., 2013b, Molnár V. \& al., 2015).

Over recent decades, this genus has received a great deal of attention from molecular phylogenetic workers following the discovery of its important phylogenetic position within Malpighiales (Davis and Chase, 2004). Indeed, the bulk of studies dealing with this order have 
93 paid much attention to samples of Elatine as representative of the family (Davis \& al., 2005; 94 Tokuoka and Tobe, 2006), and only a very recent one focused on internal phylogenetic 95 relationships within the genus (Cai \& al. 2016). Most recent studies have clearly indicated a 96 sister-group relationship between the two genera (i.e. Elatine and Bergia L.) in family 97 Elatinaceae (Korotkova \& al., 2009; Wurdack and Davis, 2009; Davis and Anderson, 2010; Xi \& 98 al., 2012), and a divergence age of 85-113 million year ago (Ma) has estimated for this lineage 99 (Davis \& al., 2005). In spite of this phylogenetic information, at the time of writing this paper we knew almost nothing about phylogenetic relationships within the genus Elatine, and so were unable to test the taxonomic hypothesis of Seubert (1845) postulated more than a century and a half ago.

To fill this gap in our knowledge, we present a molecular phylogeny of the genus Elatine in this paper that employs 27 samples from 13 species based on nuclear and plastid sequences. In addition to molecular work, we also present a morphometric analysis of seeds that enables a test of the explanatory power of seed morphology as a phylogenetic took within this genus. Our aim is to test taxonomic treatments that are currently applied as well as to provide a modern systematic treatment based on our results.

\section{MATERIALS AND METHODS}

Plant material and taxon sampling. - Plant tissue samples were collected and embedded in silica-gel from cultivated plants kept in Debrecen that encompass the taxonomic range of genus Elatine in Europe (Table 1). Elatine alsinastrum, Elatine hungarica, E. hydropiper and E. triandra are protected species and were sampled in Hungary with the permission of the Hortobágy National Park Directorate (Permission id.: 45-2/2000, 250-2/2001). Although our focus was on this region, represented by all 11 species found on the continent (i.e. four from section Crypta, six from section Elatinella), we included samples from North American members of the genus, and added Bergia texana as an outgroup. Altogether, 14 species are represented in our collection covering almost the whole section Elatinella (only E. ecuadoriensis is missing), and four species of section Crypta are also included. Cultivated plants originate from our field collections of seedling plants or seeds, sown on sterile soil and kept in climate controlled chambers. Thus, 1-5 young plants from germinated seeds were grown under constant conditions (14h/day light and $30 \mu \mathrm{mol} \mathrm{m}-2$ sec- 1 light intensity; temperatures: daytime $22 \pm 2^{\circ} \mathrm{C}$, dark hours $18 \pm 2^{\circ} \mathrm{C}$ ) to form clonal groups and in order to set seed. Plant material of a single discrete clonal group was sampled into silica-gel for DNA analysis, while mature seeds were collected from plants. These seeds were sent to the Polish co-authors in Szczecin for scanning electron microscopy (SEM).

DNA regions considered. - Since at the time of designing our study no previous molecular work has ever discovered the intra-generic molecular variability of the genus Elatine, we screened one mitochondrial region, three nuclear regions, and nine plastid regions commonly used in plant phylogenetics on three selected samples (Table S1). Of these, the nuclear ribosomal ITS (nrITS) region (Baldwin \& al., 1995; Álvarez and Wendel, 2003; Nieto-Feliner and Rosselló, 2007), the accD-psaI intergenic spacer (Small \& al., 1998), the psbJ-petA intergenic spacer (Shaw \& al., 2007), and the ycf6-psbM-trnD intergenic spacer (Shaw \& al., 2005), the latter three regions representing the plastid genome, were chosen for sequencing across the whole sample set (see Results). 
139

DNA extraction, amplification, cloning, and sequencing. - Total genomic DNA was extracted from approximately $15-30 \mathrm{mg}$ of silica-gel dried plant material, thoroughly ground in liquid nitrogen and then resuspended in lysis buffer $(2 \%$ CTAB, $20 \mathrm{mM}$ EDTA pH 8, $100 \mathrm{mM}$ Tris- $\mathrm{HCl} \mathrm{pH} \mathrm{9,} \mathrm{and} 1.4 \mathrm{mM} \mathrm{NaCl}$ ). Following incubation at $65^{\circ} \mathrm{C}$ for 60 minutes, samples were centrifuged at 20,000 g for $3 \mathrm{~min}$, before supernatant was extracted with an equal volume of chloroform and centrifuged for $10 \mathrm{~min}$ at 20,000 g. This extraction procedure was repeated twice, and DNA was precipitated with an equal volume of iso-propanol plus 0.08 volume of 7.5 $\mathrm{M}$ ammonium-acetate and stored at $-20^{\circ} \mathrm{C}$ for $1 \mathrm{~h}$. DNA was pelleted by centrifugation at 20,000 $\mathrm{g}$ for $12 \mathrm{~min}$; each pellet was washed twice with $70 \%$ ethanol, dried on open-air, and redissolved in 40-100 $\mu 10.1 \mathrm{M}$ Tris (pH 7.5).

The angiosperm-specific ITS1A (5'- GAC GTC GCG AGA AGT CCA) primer (Gulyás \& al., 2005) and the universal primer ITS4 (White \& al., 1990) were applied for polymerase chain reaction (PCR) to specifically amplify plant nrITS. The PCR reaction mixture contained 0.1 volume $10 \times$ Taq buffer with $\left(\mathrm{NH}_{4}\right)_{2} \mathrm{SO}_{4}$ (Fermentas), $200 \mu \mathrm{M}$ of each dNTPs (Fermentas), $2 \mathrm{mM}$ $\mathrm{MgCl}_{2}, 0.2 \mu \mathrm{M}$ of each primer, $1.25 \mathrm{U}$ DreamTaq Green polymerase (Fermentas), and $1 \mu \mathrm{l}$ unquantified genomic DNA extract. Amplifications were performed on an Abi Veriti 9600 thermal cycler (Applied Biosystems), programmed for an initial denaturation step at $94{ }^{\circ} \mathrm{C}$ for $4.30 \mathrm{~min}$, followed by 33 cycles of denaturation for $30 \mathrm{~s}$ at $94{ }^{\circ} \mathrm{C}$, annealing for $30 \mathrm{~s}$ at $51^{\circ} \mathrm{C}$, and extension for $30 \mathrm{~s}$ at $72^{\circ} \mathrm{C}$. Extension times were increased by one second at each cycle, and thermal cycling ended with a final extension for $7.00 \mathrm{~min}$ at $72^{\circ} \mathrm{C}$.

All plastid regions were amplified by the primers described in their corresponding publications and under the same PCR conditions. The reaction mixture was the same as described for nrITS, and the amplification regime followed a touchdown protocol: an initial denaturation step at $94^{\circ} \mathrm{C}$ for $5.00 \mathrm{~min}$, followed by 20 cycles of denaturation for $30 \mathrm{~s}$ at $94^{\circ} \mathrm{C}$, annealing for $30 \mathrm{~s}$ starting at $58^{\circ} \mathrm{C}$, decreased by $0.5^{\circ} \mathrm{C}$ in each cycle, then extension for $1.30 \mathrm{~s}$ at $72^{\circ} \mathrm{C}$, followed by 20 subsequent cycles using the same regime but keeping the annealing temperature constant at $48^{\circ} \mathrm{C}$. Thermal cycling was ended with a final extention at $72^{\circ} \mathrm{C}$ for 7.00 $\min$.

Quality and quantity of PCR products were evaluated by loading them onto a $1 \%$ agarose gel stained with ethidium bromide. For direct sequencing, unpurified PCR products were submitted to a commercial purification and sequencing service provided by Macrogen Inc. (Korea). All regions were sequenced from the forward and reverse directions using the original primers as sequencing primers. The $y c f 6-p s b M$-trnD region was amplified as a whole, but sequenced using the $p s M$ gene anchoring primers as additional internal sequencing primers.

Cloning was performed on two E. hexandra samples from Poland which showed unambiguous double-peaks in their nrITS direct sequences. These purified PCR products were ligated and transformed into the pGEM-T Easy Vector System II (Promega) following the manufacturer's instructions. Transformed cells were screened with ampicillin, and recombinant plasmid DNA was isolated from white colonies by suspending them in $40 \mu \mathrm{l}$ sterile MilliQ water, subboiling for 5 mins at $98^{\circ} \mathrm{C}$, and then centrifugating at 20,000g. The plant nrITS region was amplified and cycle-sequenced from eight and ten clones per individual in the same PCR and sequencing conditions as described above. Clone sequences were sequenced only from the forward direction. 
184

185

186

187

188

189

190

191

192

193

194

195

196

197

198

199

200

201

202

203

204

205

206

207

208

209

210

211

212

213

214

215

216

217

218

219

220

221

222

223

224

225

226

227

228

Sequence Analyses, Alignment and Phylogenetic Analyses. - Forward and reverse sequencing reads were manually checked by eye using the software Chromas Lite v.2.01 (Technelysium Pty). The nrITS sequences were carefully screened for additive polymorphic sites (i.e. overlapping peaks at certain, phylogenetically informative sites), and IUPAC ambiguity symbols were used to indicate these when two nucleotides occurred together at the electropherogram rather than an indication of ambiguous reading. In one case (E. gussonei MT) - where the additivity of a single site in the nrITS sequence was evidently from the result of two, closely related species - we used the sequences of the supposed parental species (E. gussonei LMP and E. macropoda IT) to represent this sample in our analyses. Sequences were aligned manually using BioEdit v.7.1.3 (Hall, 1999). Due to the great number of mutations separating Bergia texana from Elatine, we were unable to reliably align it in the plastid matrix. Consequently, we had to exclude it from the plastid and combined analyses, but we were able to include it in the nrITS matrix. The phylogenetic relationship between the cloned ribotypes of Polish E. hexandra samples was inferred with the software TCS v.1.21 (Clement \& al., 2000) using default parameters but allowing the connection of ribotypes 100 steps away. One of the most frequently occurring cloned ribotypes (PL1.3, PL1.10, PL2.1, PL2.7) of each ribogroup was selected to represent (see LaJeunesse and Pinzón, 2007) the cloned samples in the phylogenetic analyses. All sequences are deposited in GenBank (Table 1.)

We worked with two main data matrices. One consisted of the nuclear marker (nrITS), the second one of the plastid markers (comprising of accD-psaI, psbJ-petA, ycf6-psbM-trnD). The latter regions were combined together because the plastid genome is inherited as a unit and is not subject to significant recombination (Palmer \& al., 1988; Jansen and Ruhlman, 2012), making it readily combinable for phylogenetic analyses (Doyle, 1992; Soltis and Soltis, 1998). Given the high number of variable nucleotide sites in the above two matrices, gaps were treated as missing in subsequent analyses. Following separated analyses of the two main matrices, we checked for 'hard incongruencies' (Mason-Gamer and Kellogg, 1996; Seelanan \& al., 1997; Wendel and Doyle, 1998) in the resulting trees: branch placement was only considered to be in hard incongruence when they received $>70 \%$ bootstrap and $>0.95$ posterior probability support-an approach advocated by many workers (Daru \& al., 2013; Patchell \& al., 2014; Scheunert and Heubl, 2014), favoured over the commonly used ILD-test (Farris \& al., 1994), which can fail to correctly test combinability (Dolphin \& al., 2000; Barker and Lutzoni, 2002; Darlu and Lecointre, 2002). Since no such hard incongruence was observed, we combined the nuclear and plastid matrices into a combined matrix. Samples with nrITS sequences showing paralogy [hexandra (PL), gussonei (MT)] were only represented by their plastid sequences in this latter matrix (i.e., only their plastid sequences were used in the combined analyses, nrITS was coded as 'missing').

Heuristic searches using the Maximum Parsimony (MP) criterion were conducted on the three matrices (i.e. nuclear, plastid, combined) separately in Paup v.4.0b*10 (Swofford, 2003) using the same settings. In addition to default settings, the search utilised a tree bisection-reconnection swapping algorithm holding ten trees in each iteration step with 1,000 random sequence replicates. All most parsimonious trees (MPTs) were saved and an arbitrary chosen tree was interpreted via statistical branch support. The statistical robustness of tree topology was tested via the non-parametric bootstrap procedure (Felsenstein, 1985) using 1,000 pseudo-replicates in simple heuristic search. Branches were considered to be none $(<50 \%)$, weakly $(51-74 \%)$, moderately $(75-84 \%)$, or strongly $(>85 \%)$ supported. 
Phylogenetic trees using Bayesian inference (BI) were also constructed using the same matrices. These trees were built using the MrBayes v.3.2.2 software (Ronquist \& al., 2012) using the model-jumping feature. Thus, various possible models of molecular evolution were sampled for each gene (both single and combined data) during the analysis by taking advantage of command lset applyto = (all) nucmodel=4by 4 nst=mixed rates=gamma covarion=no;'. The combined matrix was partitioned into nuclear and plastid dataset, and these were treated separately during the runs. Two independent Markov chain Monte Carlo analyses with four simultaneous chains (one cold and three heated) for each analysis were run for ten million generations by sampling trees and parameters in every 1,000th generation, while convergence of the two runs was checked using Tracer v.1.5 (available from http://beast.bio.ed.ac.uk/software/tracer/) inspecting effective sample sizes and visually evaluating the joint-marginal densities and log likelihood traces. We discarded the first 2,500,000 generations as 'burn in' and trees were summarised using the 50 percent majority rule method. Posterior probability (PP) values of each branch were considered as test of statistical robustness treating branches with $\mathrm{PP}<0.85$ as none, $0.85-0.89$ as weakly, $0.9-0.95$ as moderately, $>0.95$ as strongly supported.

Morphometric data collection and analyses. - In addition to the molecular phylogenetic data, morphological data were collected on all species analysed here. As has been demonstrated previously (Moesz, 1908; Mifsud, 2006; Uotila, 2009c; Molnár V. \& al., 2013a; Molnár V. \& al., 2013b), the seed morphology of Elatine spp. is the most reliable character for species-level taxonomy. To obtain material for the morphometric data acquisition, field-collected seeds of the species were transferred to the laboratory, and mature plants were raised in climatic chambers. Fifty seeds were collected from mother plants, and Scanning Electron Microscopic (SEM) pictures were taken. Fifty seeds from each population were photographed and their outlines were digitised using tpsDig2 (Rohlf, 2010). The outline coordinates were transformed using HangleFourier (Haines and Crampton, 2000) function using the PAST v.1.7c (Hammer \& al., 2001) program, and statistical analyses were carried out based on on Hangle coefficients. In order to determine the relationships between predefined groups, a linear discriminant analysis was conducted such that a priori groups were populations. The group centroids were visualised on scatter plots, and Wilks's $\lambda$ was used to measure the discriminatory power of the model with values changing from 0 (perfect discrimination) to 1 (no discrimination). Classification was made using the Jackknifed grouping function in PAST; this method, one known specimen is left out each iteration, and assigned using the discriminant function which is calculated based on all the cases except that given. The numbers of correct assignments were used to evaluate the usefulness of the discriminant function. High numbers of correct assignments indicate diagnostic differences between the surveyed groups. We also used pair-wise MANOVA to test the statistical significance between groups.

\section{RESULTS}

Initial screen of sequence variability. - The twelve regions initially checked for phylogenetic variability showed (Table S1) the typical situation for plants (Soltis and Soltis, 1998); nuclear regions were most variable, followed by plastid intergeneric spacers, and plastid genes, while the mitochondrion-encoded nad6 gene was the least variable between the outgroup and the two ingroups. Amongst nuclear genes, nrITS was found to be the most variable, while 
$275 y c f 6-p s b M$, trnL-trnF, accD-psaI, and psbJ-petA changed the most of the plastid regions. It is 276 noticeable that At103 and Eif $3 E$ showed extensive paralogy in some pilot sequencings of 277 additional Elatine material; thus, we excluded these from further work. Although it was amongst 278 the highly variable regions, the trnH-psbA sequence was also excluded as this marker produced 279 unreadable direct sequences; some pilot sequences showed abrupt unreadability in the middle

280

281

282

283

284

285

286

287

288

289

290

291

292

293

294

295

296

297

298

299

300

301

302

303

304

305

306

307

308

309

310

311

312

313

314

315

316

317

318

319

320 portion of the intergeneric spacer, but what was recovered at the other end of the region was as if it had length-different paralogous copies. Finally, the region $p s b M$-trnD, albeit its relative invariability, was used, and sequenced, as it was convenient to include together with the highly variable $y c f 6-p s b M$ region.

Molecular phylogenetic relationships. - The parsimony analysis of the nrITS matrix found two equally MPTs of 235 steps with negligible homoplasy (consistency index $(\mathrm{CI})=0.8851$, homoplasy index $(\mathrm{HI})=0.1149$, retention index $(\mathrm{RI})=0.9403)$. These trees differ from each other in the main clustering 'above E. alsinastrum', which is not supported by bootstrap analysis and not discussed further. One of the MPTs with support information is displayed as a phylogram (Fig. 2.A), with Bergia texana, representative of the sister genus, placed at the root. The following branches towards the tips are not resolved; although placed sister to the rest of the genus in the parsimony analysis, the sister relationship of Elatine alsinastrum is not supported in subsequent bootstrap analysis. There are four more clades identifiable with statistical confidence; that including E. brochonii, E. hexandra, E. brachysperma, E. triandra (including E. ambigua and two clones of Polish E. hexandra), and the clade of tetramerous species. Within the latter, the temperate representatives of this group are sister to the mediterranean species, which also split into two clades, one containing most $E$. macropoda and E. campylosperma samples, and a second containing all E. gussonei samples plus a Turkish E. macropoda accession. Within the temperate species of this lineage there is almost no resolution with the exception of the two $E$. hydropiper accessions which are placed as sisters to each other. The tree obtained by BI totally supports this topology as all branches, found to be supported by the MP bootstrap procedure, were also supported by PP values and thus did not collapse on the majority rule consensus tree of $\mathrm{BI}$ (not shown). Therefore, only the PP values are shown on the corresponding branches.

The MP analysis of the plastid dataset found two equally MPTs 315 steps in length with negligible homoplasy $(\mathrm{CI}=0.9016, \mathrm{HI}=0.0984, \mathrm{RI}=0.9556)$. One of these, with support information, is displayed as a phylogram (Fig. 2.B), but as we were unable to reliably align Bergia in this dataset, it was left out from here, and our use of E. alsinastrum as an alternative outgroup was not supported. From this split towards the tips the branches usually receive high statistical support, with $E$. brochonii branching off first. This was followed by E. brachysperma and E. triandra clade. The tetramerous clade is again well-supported, but on the plastid tree (Fig. 2.B) we find E. campylosperma to be sister to the rest of the group, although this relationship is weakly supported. There is less resolution at the next level of branches, where a strongly supported branch separates E. macropoda and two E. gussonei (MT and LMP) samples from the rest, then all other E. gussonei samples form a clade, E. hexandra samples form a clade, finally the temperate members of the tetramerous species form a clade. Unlike on the nrITS tree, there is resolution in the latter clade as the North American E. californica branches first, this is followed by E. orthosperma what is sister to the E. hungarica plus E. hydropiper clade, where we find no resolution. again the majority rule consensus tree found by BI had a fully corroborative topology (not shown), therefore, only the PP values are shown on the MP phylogram at the corresponding branches. 
Regarding testing the species delimitation of a priori taxa, multiple accessions of the same species, in most cases, formed strongly supported monophyletic groups. Nevertheless, there were some significant exceptions on the nrITS tree (Fig. 2.A), including the Turkish E. macropoda sample was clustered together with E. gussonei samples, the Spanish E. campylosperma sample was clustered together with the E. macropoda samples. On the plastid tree only the E. gussonei samples fell into two separate clade, with two accessions from Malta and Lampedusa sister to $E$. macropoda, and three accessions of E. gussonei from Italy, Spain and Morocco clustered separately.

There were some incongruent placement of branches, but these only affected tip, or close to, tip branches. The most important of these concerns E. campylosperma, nested within the Mediterranean clade on the nrITS tree, but placed as sister to the rest of the tetramerous clade on the plastid tree. Secondly, samples of E. hexandra are either placed as sister to E. brochonii (although with weak support) or together with E. triandra on the nrITS tree, while these samples are found nested within the clade comprising the three E. gussonei listed above as well as the temperate members of the tetramerous plants.

The TCS-analysis of nrITS clones of Polish E. hexandra unravelled the existence of two ribotype-groups within the same individuals (Fig. 3); these two groups were separated by 22 mutation steps. When included in a wide phylogenetic context (Fig. 2.A) the representative ribotypes fall into two very distant clades on the nrITS tree; one group of clones are inseparable from E. triandra and E. ambigua direct sequences, while the other group forms a separate clade together with direct sequences of $E$. hexandra, sister to E. brochonii.

When we combined the nrITS and plastid dataset the MP search found a single MPT of 443 steps containing little homoplasy $(\mathrm{CI}=0.8375, \mathrm{HI}=0.1625, \mathrm{RI}=0.9322)$ (Fig. 4). Bootstrap analysis recovered support for all branches but the placement of $E$. alsinastrum at the root, the placement of Polish E. triandra as sister to the E. ambigua sample, and the relationship between $E$. hungarica samples remained unresolved. In addition, most nodes are highly supported by bootstrap values, and the analysis using BI also found a most credible phylogenetic tree with the very same topology as the MP tree. Again, this tree is not shown, just the PP values are indicated on its counterpart. Multiple accessions of the same a priori species form strongly supported clades in the combined dataset, with the exception is E. hungarica, where samples are not resolved as monophyletic on either tree; another one concerns the samples of E. gussonei, which fall into two separate, closely related clades on the trees.

Morphometric comparison of seeds. - Measured populations of different Elatine species proved to be significantly different based on seed outlines, a result with high discriminatory power (Wilks's $\lambda=0.00004, p<0.001$ ). The first axis explained $75 \%$ and the second $12 \%$ of variance between groups; on the scatter plot of group centroids four morpho-groups can be recognized, straight (I.), curved (II.), highly curved (III.), and an intermediate (IV.) form between curved and straight (Fig. 5). Surprisingly, the results of the post-hoc test indicated that nearly all predefined groups were significantly different from each other except the two Elatine hexandra populations (Table S2). The cross-validated classification correctly assigned $64.1 \%$ of the specimens, while classification success varies to a relatively large degree $20 \%-96 \%$ between the groups (Table S3).

\section{DISCUSSION}


In this paper we provide a detailed molecular phylogenetic study of the genus Elatine by sequencing and analysing the nuclear rITS region and four plastid regions in multiple accessions of 13 species. Through analysis of a combined nuclear and plastid data matrix have provided the most resolved and reliable phylogenetic hypothesis for the studied taxa, and are able to interpret the phylogenetic relationships hypothezied by this tree (Fig. 4).

Molecular phylogenetic relationships. - Although morphologically highly different (Fig. 1), E. alsinastrum was placed equivocally as sister to the rest of the genus. In contrast, E. brochonii, a trimerous flowered, haplostemon species of the western mediterranean was placed at the base of the tree. We have to note here that the analysis of Cai \& al. (2016) placed this species unequivocally as sister to the rest of the genus, but that analysis lacked E. brochonii. The rest of the species analysed here are split into two main lineages, most probably representing the two main clades of the genus Elatine. One corresponds to the traditional section Crypta, and consists of trimerous flowered, haplostemon species with slightly or non-curved seeds (E. ambigua, E. brachysperma, E. triandra). The North American species thus apparently represent a separate lineage, and - together with the high species diversity of trimerous, haplostemon species found on this continent - hint at the North American diversification and origin of the Crypta clade.

Within the diplostemon clade, E. hexandra branches first as sister to the rest; although this result is statistically highly supported, a stabilised hybrid origin of this species can be postulated based on its phylogenetic position. This placement of lineages could be indicative of hybrid origin, as discussed in detail by Funk (1985), and is further corroborated by the presence of phylogenetically very distantly related ribotypes (Fig. 3) within the same individual, derived from the Crypta and the E. brochonii lineage (Fig. 2A). Furthermore, Uotila (2009a) reported the presence of morphological instability in this species, as three and exceptionally four carpels can be observed. Highest ploidy level (dodecaploidy) can also be found in this species (Jankun, 1989), perhaps the result of allopolyploidisation (Wendel, 2000), and could have prevented the completion of concerted evolution of nrITS arrays located on non-homologous chromosomes (Wendel \& al., 1995; Álvarez and Wendel, 2003). Thus, on the basis of these arguments, we conclude an allopolyploid hybrid origin for the species E. hexandra. Although its exact origin is equivocal, E. triandra as one parent can be stated with high certainty, while high ploidy level in this species might be the sign of the involvement of more than one additional taxa. Additional ribotypes hint at an E. brochonii-like ancestral species (trimerous flowers, slightly curved seeds, haplostemon adroecium), while the plastid affinity to tetramerous members of the genus clearly indicates genome donors with tetramerous flowers.

The other main lineage within this section of the tree is represented by the tetramerous flowered, diplostemon species of section Elatinella. The species in this lineage can further be divded into two main sub-lineages: one consist of species with Temperate distribution (Fig. 4: clade D), while the other one includes species of mediterranean distribution (Fig. 4: clade E). Out of these, all but E. californica (North American), E. hungarica, and E. hydropiper (both Palearctic) are confined geographically to the European continent, where the diversification of section Elatinella might have taken place. Nonetheless, the placement of E. californica close to the root of this clade can imply a Nearctic origin for the section; this group might have originated in North America and then later diversified in the Old World. However, this is in contrarst to the result of Cai \& al. (2016), who postulated a Eurasian origin of the genus. Within clade D, the northern Eurasian E. orthosperma is hypothesised to be sister to the species-pair E. hungarica 
413 and E. hydropiper, which show certain vicariance; the former is typical of the Eurasian steppe 414 zone (Lukács \& al., 2013), while the latter can be considered to be an atlantic-boreal species 415 inhabiting more northern latitudes in Eurasia (Popiela \& al., 2012).

416 The other main sublineage (clade E) is represented by species inhabiting the Mediterranean 417 basin, including E. campylosperma, E. gussonei, and E. macropoda. The species branching the 418 earliest is E. campylosperma, a taxonomically neglected species (see below). This is followed by 419 E. gussonei, what is further split into two lineages, the western Mediterranean samples form a 420 separate clade, while plants from Malta and Lampedusa are sister to a monophyletic $E$. 421 macropoda. However, there are some notable incongruencies between the trees obtained from 422

423

424

425

426

427

428

429

430

431

432

433

434

435

436

437

438

439

440

441

442

443

444

445

446

447

448

449

450

451

452

453

454

455

456 contrastingly inherited markers (Fig. 2), including the Spanish E. campylosperma has identical nrITS to E. macropoda, but shares plastid haplotypes with the other E. campylosperma from Italy including the Turkish E. macropoda is included in the E. gussonei clade on the nrITS tree, nested within the E. macropoda clade on the plastid tree. These incongruent placements on trees of differently inherited markers are commonly explained by recent hybridisation (Rieseberg \& al., 1996; Wendel and Doyle, 1998). Indeed, these Mediterranean species of Elatine have much bigger and conspicuous flowers compared to their Temperate siblings (Fig. 1), which probably promotes cross-pollination by insects, opening the way to hybridisation of these species that often occur in sympatry. Indeed, the merging of E. macropoda and E. gussonei ribotypes in the Maltese E. gussonei accession directly demonstrates this capability of setting seed by crosspollination in this predominantly selfing genus.

Seed morphometrics in Elatine. - On the one hand, our results clearly indicate that the outline of seeds alone is not suitable for species delimitation, while on the other, four morphogroups can be recognized in the in the CVA plots among Elatine, including straight, highly curved, curved, and an intermediate seed shape which are clearly identifiable. Based on the phylogenetic relationships among species it seems that these main seed shapes do not form monophyletic units; the straight seed shape appears in both the earlier and the most recently divergent species, suggesting that they could have evolved multiple times during the evolution of the genus. Therefore, seed shape alone can only be used to define species within a given evolutionary lineage.

Species delimitation in Elatine. - The inclusion of multiple accessions of the same a priori species enabled us to test the species delimitations and specific characters used in the taxonomy of this genus. As demonstrated on the plastid tree (Fig. 2B) and on our combined tree, in most cases multiple accessions of the same species were grouped into the same tip clade. This is one clear indication of the genetic cohesiveness of this species as interpreted in the current taxonomy of the genus (Cook, 1968; Uotila, 2009b), although these tip clades are placed on rather long branches in phylograms (Fig. 2, Fig. 4A) indicating substantial genetic differentiation. One notable exception, however, is the E. hungarica - E. hydropiper sibling species, where there is a significant difference in seed characteristics (Fig. 5). Similarly, no substantial genetic differences exist between our E. ambigua and E. triandra samples, corroborated by seed characteristics. Thus, given the certain identification of our E. ambigua sample - the presence of significant pedicels, the diagnostic character of this species (Cook, 1968) - we are confident these samples are taxonomically equivalent, thus questioning the presence of the Asian E. ambigua in Europe. 457 In fact, our field experience also suggest this as we repeatedly found E. triandra specimens - 
usually in full sunshine - with long pedicels in Hungary. This probably also explains why there are scattered and ephemeral observations of this species in Europe (Moesz, 1908; Cook, 1968).

Probably the most conspicuous discrepancy in species delimitation concerns E. gussonei, a neglected species of the Mediterranean basin (Mifsud, 2006; Kalinka \& al., 2014). Our samples of this species fall into two distinct clade (Fig. 4), one which includes the sample from the nomenclatural type locality of Lampedusa (Molnár V. \& al., 2013b) is sister to E. macropoda, while the other, including mostly western Mediterranean samples, forms a separate monophyletic lineage. This substantial genetic difference has to be further studied, but most probably merits taxonomic recognition at at least the subspecies level.

Finally, the presence of an almost forgotten species of European Elatine, E. campylosperma, should be discussed. This plant was described by Seubert (1842) from Sardinia, but was later neglected by most workers who synonymized it under E. macropoda (Cook, 1968; Uotila, 2009b; Popiela \& Łysko, 2010). Our data show that plants with highly curved seeds and conspicuous flowers from the Mediterranean basin can be distinguished as separate molecular and morphological entities, and our ongoing taxonomical investigation suggests that these should be treated as E. campylosperma.

Taxonomic implications. - On the basis of the well-resolved molecular phylogenetic tree presented in this paper (Fig. 4), we test the currently used systematic treatment of the genus Elatine proposed originally by Seubert (1845). We corroborate the earlier observation that section Crypta is monophyletic, although our sampling was not focused on this group. In contrast, the other section Elatinella was found to be polyphyletic, including the species $E$. brochonii. Disregarding this species, the section is monophyletic further demonstrating the utility of floral morphological characters used in the systematics of Elatine.

Nevertheless, more details are unravelled in this study regarding the intra-sectional genetic lineages and chromosome number characteristics of Elatine section Elatinella (summarised on Fig. 4). Based on these results, we devise the following new section corresponding to clade A, and two new subsections corresponding to clade D and clade E (on Fig. 4):

Bracteata Sramkó, A. Molnár \& Popiela, sect. nov. - Type: E. brochonii Clav.

Morphology - Stems 1-10 cm long, erect or prostrate, leaves elliptical, oval or oblong; leafy bracts; two-five trimerous, diplostemonous, sessile flowers in cyme; the supreme flower single, six stamens; seeds straight.

Diagnostic characters. - leafy bracts; the supreme flower single; short, straight seeds.

Etymology. - The section was named on the basis of the significant and characteristic bracts of the only species.

Distribution. - western-Mediterranean (Morocco, Algeria, Spain, Portugal, France, Corsica).

Accepted species. - Elatine brochonii.

Hydropiperia Sramkó, A. Molnár \& Popiela, subsect. nov. - Type: E. hydropiper L.

Morphology - Shoots branched, rooting at nodes and creeping, 1-10 cm long; leaves oblong, ovale or spatulate; one-two flowers per node, axillary, diplostemonous, tetramerous, sessile or short pedicelled (elongating in fruit), eight stamens; seeds horseshoe, crescent-shaped or long and straight (E. orthosperma).

Diagnostic characters. - Procumbent and node-rooting plants; short or very short pedicels, mostly moderate zone, blooms summer/autumn (VI-X). 
504

505

506

507

508

509

510

511

512

513

514

515

516

517

518

519

520

521

522

523

524

525

526

527

528

529

530

531

532

533

534

535

536

537

538

539

540

541

542

543

544

545

546

547

548

Etymology. - This subsection was named after its most widespread species (E. hydropiper).

Distribution. - Circumboreal (Eurasia, North-America).

Accepted species. - Elatine californica, E. hungarica, E. hydropiper, and E. orthosperma.

Macropodae Sramkó, A. Molnár \& Popiela, subsect. nov. - Type: E. macropoda Guss.

Morphology: Plants about $10 \mathrm{~cm}$ long with long internodes, most frequently upright stem, sometimes rooting at nodes and creeping; leaves obovate or oblong obovate; diplostemonous, tetramerous flowers on long pedicels, usually one per node; eight stamens; seeds slightly curved, comma-shaped or horseshoe.

Diagnostic characters. - Long pedicel, usually erect; Mediterranean zone; blooms winter/spring (I-IV).

Etymology. - This subsection was named after E. macropoda.

Distribution. - Mediterranean: mainly on coastal zones and archipelago of the Mediterranean Sea.

Accepted species. - Elatine campylosperma, E. gussonei, E. macropoda.

\section{ACKNOWLEDGEMENTS}

We gratefully acknowledge the field assistance of Endre Bajka, Bartosz Kurnicki, Gergely Gulyás, Gusztáv Jakab, Andrzej Łysko, Viktor Löki, Attila Mesterházy, Edvárd Mizsei, Ágnes Mosolygó-Lukács, Arkadiusz Nowak, Sylwia Nowak, Norbert Pfeiffer, Lajos Somlyay, Antal Széll, László Tóth, and Róbert Vidéki, as well as the laboratory assistance of Kaan Hürkan, ÁgnesMosolygó-Lukács. Thank the staff of the Centre for Molecular Biology, University of Szczecin - Bożena Białecka and Magdalena Bihun - for taking the scanning electron micrographs. We appreciate the work of our reviewers, and are much grateful to Gareth Dyke for his improvements on the English of our work.

\section{LITERATURE CITED}

Albrecht, D.E. 2002. Elatine macrocalyx (Elatinaceae), a new species from central and western Australia. Nuytsia 14:319-324.

Álvarez, I., \& Wendel, J.F. 2003. Ribosomal ITS sequences and plant phylogenetic inference. Mol. Phylogenet. Evol. 29:417-434.

Baldwin, B.G., Sanderson, M.J., Porter, J.M., Wojciechowski, M.F., Campbell, C.S., \& Donoghue, M.J. 1995. The ITS region of nuclear ribosomal DNA: a valuable source of evidence on angiosperm phylogeny. Ann. Missouri Bot. Gard. 82:247-277.

Barker, F.K., \& Lutzoni, F.M. 2002. The utility of the Incongruence Length Difference test. Syst. Biol. 51:625-637.

Cai, L., Xi, Z., Peterson, K., Rushworth, C., Beaulieu, J. \& Davis, C. C. 2016 Phylogeny of Elatinaceae and the tropical Gondwanan origin of the Centroplacaceae (Malpighiaceae, Elatinaceae) Clade. PLoS ONE 11(9): e0161881.

Clement, M., Posada, D., \& Crandall, K.A. 2000. TCS: a computer program to estimate gene genealogies. Mol. Ecol. 9:487-494. 
Cook, C.D.K. 1968. Elatine L. in: Tutin, T.G., Heywood, V.H., Burges, N.A., Moore, D.M., Valentine, D.H., Walters, S.M., \& Webb, D.A., (eds), Flora Europaea. Vol. 2. Cambridge University Press, Cambridge. Pp: 295-296.

Darlu, P., \& Lecointre, G. 2002. When does the Incongruence Length Difference test fail? Molec. Biol. Evol. 19:432-437.

Daru, B.H., Manning, J.C., Boatwright, J.S., Maurin, O., Maclean, N., Schaefer, H., Kuzmina, M., \& van der Bank, M. 2013. Molecular and morphological analysis of subfamily Alooideae (Asphodelaceae) and the inclusion of Chortolirion in Aloe. Taxon 62:62-76.

Davis, C.C., \& Anderson, W.R. 2010. A complete generic phylogeny of Malpighiaceae inferred from nucleotide sequence data and morphology. Amer. J. Bot. 97:2031-2048.

Davis, C.C., \& Chase, M.W. 2004. Elatinaceae are sister to Malpighiaceae; Peridiscaceae belong to Saxifragales. Amer. J. Bot. 91:262-273.

Davis, Charles C., Webb, Campbell O., Wurdack, Kenneth J., Jaramillo, Carlos A., \& Donoghue, Michael J. 2005. Explosive radiation of Malpighiales supports a midCretaceous origin of modern tropical rain forests. The American Naturalist 165:E36-E65.

Dolphin, K., Belshaw, R., Orme, C.D.L., \& Quicke, D.L.J. 2000. Noise and incongruence: Interpreting results of the Incongruence Length Difference Test. Mol. Phylogenet. Evol. 17:401-406.

Doyle, J.J. 1992. Gene trees and species trees: molecular systematics as one-character taxonomy. Syst. Bot. 17:144-163.

Farris, J.S., Källersjö, M., Kluge, A.G., \& Bult, C. 1994. Testing significance of incongruence. Cladistics 10:315-319.

Felsenstein, J. 1985. Confidence limits on phylogenies: An approach using the Bootstrap. Evolution 39:783-791.

Funk, V.A. 1985. Phylogenetic patterns and hybridization. Ann. Missouri Bot. Gard.:681-715.

Garneau, M. 2006. Elatine ojibwayensis sp.nov., une nouvelle espèce d'Elatinaceae et revue des Elatinaceae du Québec. Canadian Journal of Botany 84:1037-1042.

Gulyás, G., Sramkó, G., Molnár, V.A., Rudnóy, S., Illyés, Z., Balázs, T., \& Bratek, Z. 2005. Nuclear ribosomal DNA ITS paralogs as evidence of recent interspecific hybridization in the genus Ophrys (Orchidaceae). Acta Biol. Cracov., Ser. Bot. 47:61-67.

Haines, A.J., \& Crampton, J.S. 2000. Improvements to the method of Fourier shape analysis as applied in morphometric studies. Palaeontology 43:765-783.

Hall, T.A. 1999. BioEdit: a user-friendly biological sequence alignment editor and analysis program for Windows 95/98/NT. Nucleic Acids Symposium Series 41:95-98.

Hamilton, M.B. 1999. Four primer pairs for the amplification of chloroplast intergenic regions with intraspecific variation. Mol. Ecol. 8:521-523.

Hammer, Ø., Harper, D.A.T., \& Ryan, P.D. 2001. PAST: Paleontological statistics software package for education and data analysis. Palaeontologia Electronica 4:9.

Hoot, S.B., Culham, A., \& Crane, P.R. 1995. The utility of atpB gene sequences in resolving phylogenetic relationships: Comparison with $r b c L$ and $18 \mathrm{~S}$ ribosomal DNA sequences in the Lardizabalaceae. Ann. Missouri Bot. Gard. 82:194-207.

Jankun, A. 1989. Further studies in chromosome numbers of Polish angiosperms. Part XXII. Acta Biol. Cracov., Ser. Bot. 31:1-17.

Jansen, R.K., \& Ruhlman, T.A. 2012. Plastid genomes of seed plants. in: Bock, R., \& Knoop, V., (eds), Genomics of chloroplasts and mitochondria. Springer, Dordrecht.Pp: 103-126. 
595

596

597

598

599

600

601

602

603

604

605

606

607

608

609

610

611

612

613

614

615

616

617

618

619

620

621

622

623

624

625

626

627

628

629

630

631

632

633

634

635

636

637

638

639

Kalinka, A., Mifsud, S., Popiela, A., \& Achrem, M. 2014. Chromosome number of Elatine gussonei (Sommier) Brullo (Elatinaceae) and its distribution on the Maltese islands. Acta Bot. Croat. 73:267-273.

Korotkova, N., Schneider, J., Quandt, D., Worberg, A., Zizka, G., \& Borsch, T. 2009. Phylogeny of the eudicot order Malpighiales: analysis of a recalcitrant clade with sequences of the petD group II intron. Plant Syst. Evol. 282:201-228.

Kubitzki, K. 2014. Elatinaceae. in: Kubitzki, K., (ed), Flowering Plants. Eudicots. Malpighiales. Springer, Berlin Heidelberg. Pp: 39-41.

Lægaard, S. 2008. Elatine rotundifolia sp. nov.(Elatinaceae) from Ecuador. Nord. J. Bot. 26:235-236.

LaJeunesse, T.C., \& Pinzón, J.H. 2007. Screening intragenomic rDNA for dominant variants can provide a consistent retrieval of evolutionary persistent ITS (rDNA) sequences. Mol. Phylogenet. Evol. 45:417-422.

Li, M., Wunder, J., Bissoli, G., Scarponi, E., Gazzani, S., Barbaro, E., Saedler, H., \& Varotto, C. 2008. Development of COS genes as universally amplifiable markers for phylogenetic reconstructions of closely related plant species. Cladistics 24:727-745.

Lukács, B.A., Sramkó, G., \& Molnár V, A. 2013. Plant diversity and conservation value of continental temporary pools. Biol. Conserv. 158:393-400.

Mason-Gamer, R.J., \& Kellogg, E.A. 1996. Testing for phylogenetic conflict among molecular data sets in the tribe Triticeae (Gramineae). Syst. Biol. 45:524-545.

Mason, H.L. 1956. New species of Elatine in California. Madroño 13:239-240.

Mifsud, S. 2006. A comparative study between Elatine gussonei (from Malta) and Elatine macropoda (from Majorca) Aquatic Gardeners [Serial Online]:Available at http://www.aquatic-gardeners.org/Articles/elatine/Comparitive_study.pdf (accessed 19.05.2014.).

Moesz, G. 1908. Magyarország Elatine-i [Elatine species of Hungary]. Magyar Botanikai Lapok $7: 2-35$.

Molnár V., A., Horváth, O., Tökölyi, J., \& Somlyay, L. 2013a. Typification and seed morphology of Elatine hungarica (Elatinaceae). Biologia 68:210-214.

Molnár V., A., Popiela, A., \& Lukács, B.A. 2013b. Elatine gussonei (Sommier) Brullo et al. (Elatinaceae) in Sicily. Plant Biosystems 148:27-30.

Molnár V., A, Tóth, J. P., Sramkó, G., Horváth, O., Popiela, A., Mesterházy, A., Lukács, B. A. 2015. Flood induced phenotypic plasticity in amphibious genus Elatine (Elatinaceae). - PeerJ 3:e1473.

Niedenzu, F.J. 1925. Elatinaceae. in: Engler, A., \& Prantl, K., (eds), Die Naturlichen Pflanzenfamilien. 2. Auflage. Band 21. W. Engelmann, Lepzing.Pp: 270-276.

Nieto-Feliner, G., \& Rosselló, J.A. 2007. Better the devil you know? Guidelines for insightful utilization of nrDNA ITS in species-level evolutionary studies in plants. Mol. Phylogenet. Evol. 44:911-919.

Palmer, J.D., Jansen, R.K., Michaels, H.J., Chase, M.W., \& Manhart, J.R. 1988. Chloroplast DNA variation and plant phylogeny. Ann. Missouri Bot. Gard. 75:1180-1206.

Patchell, M.J., Roalson, E.H., \& Hall, J.C. 2014. Resolved phylogeny of Cleomaceae based on all three genomes. Taxon 63:315-328.

Popiela, A., \& Lysko, A. 2010. The distribution of Elatine macropoda Guss. (Elatinaceae). Acta Societatis Botanicorum Poloniae 79:81-86. 
640

641

642

643

644

645

646

647

648

649

650

651

652

653

654

655

656

657

658

659

660

661

662

663

664

665

666

667

668

669

670

671

672

673

674

675

676

677

678

679

680

681

682

683

684

Popiela, A., Lysko, A., \& Molnár V., A. 2013. Recent distribution of the Euro-Siberian-subMediterranean species Elatine alsinastrum L. (Elatinaceae). Acta Bot. Croat. 72:375386.

Popiela, A., Lysko, A., Wieczorek, A., \& Molnár V., A. 2012. The distibution of Elatine hydropiper L. (Elatinaceae). Acta Societatis Botanicorum Poloniae 81:137-143.

Popiela, A., Lysko, A., Wieczorek, A., \& Nalepka, D. 2011. The distribution of Elatine hexandra (Lapierre) DC. (Elatinaceae). Acta Societatis Botanicorum Poloniae 80:27-32.

Rieseberg, L.H., Whitton, J., \& Linder, C.R. 1996. Molecular marker incongruence in plant hybrid zones and phylogenetic trees. Acta Bot. Neerl. 45:243-262.

Ronquist, F., Teslenko, M., van der Mark, P., Ayres, D.L., Darling, A., Höhna, S., Larget, B., Liu, L., Suchard, M.A., \& Huelsenbeck, J.P. 2012. MrBayes 3.2: efficient Bayesian phylogenetic inference and model choice across a large model space. Syst. Biol. 61:539542.

Scheunert, A., \& Heubl, G. 2014. Diversification of Scrophularia (Scrophulariaceae) in the Western Mediterranean and Macaronesia - Phylogenetic relationships, reticulate evolution and biogeographic patterns. Mol. Phylogenet. Evol. 70:296-313.

Schmidt-Mumm, U., \& Bernal, H. 1995. A new species of Elatine (Elatinaceae) from the Colombian páramos in the northern Andes. Brittonia 47:27-30.

Seelanan, T., Schnabel, A., \& Wendel, J.F. 1997. Congruence and consensus in the Cotton tribe (Malvaceae). Syst. Bot. 22:259-290.

Seubert, M.A. 1842. Elatinaceae. in: Walpers, G.G., (ed), Repertorium botanices systematicae. Tomus 1. Sumtibus Friderici Hofmeister, Lipsiae.Pp: 283-286.

Seubert, M.A. 1845. Elatinarum monographia. Academia Caesarea Leopoldino-Carolina Nova Acta 21:34-60.

Shaw, J., Lickey, E.B., Beck, J.T., Farmer, S.B., Liu, W.S., Miller, J., Siripun, K.C., Winder, C.T., Schilling, E.E., \& Small, R.L. 2005. The tortoise and the hare II: Relative utility of 21 noncoding chloroplast DNA sequences for phylogenetic analysis. Amer. J. Bot. 92:142-166.

Shaw, J., Lickey, E.B., Schilling, E.E., \& Small, R.L. 2007. Comparison of whole chloroplast genome sequences to choose noncoding regions for phylogenetic studies in angiosperms: The tortoise and the hare III. Amer. J. Bot. 94:275-288.

Small, R.L., Ryburn, J.A., Cronn, R.C., Seelanan, T., \& Wendel, J.F. 1998. The tortoise and the hare: Choosing between noncoding plastome and nuclear ADH sequences for phylogeny reconstruction in a recently diverged plant group. Amer. J. Bot. 85:1301-1315.

Soltis, D.E., \& Soltis, P.S. 1998. Choosing an approach and an appropriate gene for phylogenetic analysis. in: Soltis, D.E., Soltis, P.S., \& Doyle, J.J., (eds), Molecular Systematics of Plants II. Springer US.Pp: 1-42.

Swofford, D.L. 2003. PAUP*. Phylogenetic Analysis Using Parsimony (*and Other Methods). Version 4. Sinauer Associates, Sunderland, Massachusetts.

Taberlet, P., Gielly, L., Pautou, G., \& Bouvet, J. 1991. Universal primers for amplification of 3 noncoding regions of chloroplast DNA. Plant Mol. Biol. 17:1105-1109.

Takács, A., Schmotzer, A., Jakab, G., Deli, T., Mesterházy, A., Király, G., Lukács, B.A., Balázs, B., Perić, R., J. Pavol, E., Sramkó, G., Tökölyi, J., \& Molnár, A.V. 2013. Key environmental variables affecting the distribution of Elatine hungarica in the Pannonian Basin. Preslia 85:193-207. 
685

686

687

688

689

690

691

692

693

694

695

696

697

698

699

700

701

702

703

704

705

706

707

708

709

710

711

712

713

714

715

716

717
Tokuoka, T., \& Tobe, H. 2006. Phylogenetic analyses of Malpighiales using plastid and nuclear DNA sequences, with particular reference to the embryology of Euphorbiaceae sens. str. J. Pl. Res. 119:599-616.

Tucker, G.C. 1986. The genera of Elatinaceae in the southeastern United States. Journal of the Arnold Arboretum 67:471-483.

Uotila, P. 2009a. Elatinaceae. in: Jonsell, B., \& Karlsson, T., (eds), Flora Nordica Vol. 6. Swedish Museum of Natural History and the Royal Swedish Academy of Sciences, Stockholm.Pp: 62-69.

Uotila, P. 2009b. Elatinaceae. - In: Euro+Med Plantbase - the information resource for EuroMediterranean plant diversity. http://ww2.bgbm.org/EuroPlusMed/ [accessed 19.05.2014.]. In. Botanic Garden and Botanical Museum Berlin-Dahlem, Berlin-Dahlem. p http://ww2.bgbm.org/EuroPlusMed/ [accessed 19.05.2014.]. .

Uotila, P. 2009c. Lectotypifications in Elatine (Elatinaceae) and some taxonomic remarks. Ann. Bot. Fenn. 46:90-94.

Wendel, J. 2000. Genome evolution in polyploids. in: Doyle, J., \& Gaut, B., (eds), Plant Molecular Evolution. Springer Netherlands.Pp: 225-249.

Wendel, J., \& Doyle, J. 1998. Phylogenetic incongruence: Window into genome history and molecular evolution. in: Soltis, D., Soltis, P., \& Doyle, J., (eds), Molecular Systematics of Plants II. Chapman \& Hall, London.Pp: 265-296.

Wendel, J.F., Schnabel, A., \& Seelanan, T. 1995. Bidirectional interlocus concerted evolution following allopolyploid speciation in cotton (Gossypium). PNAS 92:280-284.

White, T.J., Bruns, T.D., Lee, S., \& Taylor, J.W. 1990. Amplification and direct sequencing of fungal ribosomal RNA genes for phylogenetics. in: Innis, M.A., Gelfand, D.H., Sninsky, J.J., \& White, T.J., (eds), PCR protocols: A guide to methods and applications. Academic Press, San-Diego.Pp: 315-322.

Wurdack, K.J., \& Davis, C.C. 2009. Malpighiales phylogenetics: Gaining ground on one of the most recalcitrant clades in the angiosperm tree of life. Amer. J. Bot. 96:1551-1570.

Xi, Z., Ruhfel, B.R., Schaefer, H., Amorim, A.M., Sugumaran, M., Wurdack, K.J., Endress, P.K., Matthews, M.L., Stevens, P.F., Mathews, S., \& Davis, C.C. 2012. Phylogenomics and a posteriori data partitioning resolve the Cretaceous angiosperm radiation Malpighiales. PNAS 109:17519-17524. 
719 Table 1. The samples included in this study; species sampled, sample origins, abbreviated 720 sample names (as appear on phylogenetic trees) and GenBank accession numbers.

721

722

\begin{tabular}{|c|c|c|c|c|c|c|c|c|}
\hline \multirow[t]{2}{*}{ Species } & \multirow[t]{2}{*}{ Locality } & \multirow{2}{*}{$\begin{array}{l}\text { Lat. } \\
\left({ }^{\circ} \mathrm{N}\right)\end{array}$} & \multirow{2}{*}{$\begin{array}{l}\text { Long. } \\
\left({ }^{\circ} \mathrm{E}\right)\end{array}$} & \multirow{2}{*}{$\begin{array}{l}\text { Abbreviated } \\
\text { name }\end{array}$} & \multicolumn{4}{|c|}{ GenBank accession numbers } \\
\hline & & & & & nrITS & $\begin{array}{c}a c c D- \\
p s a I\end{array}$ & $\begin{array}{l}\text { psbJ- } \\
\text { petA }\end{array}$ & $\begin{array}{c}y c f 6- \\
p s b M- \\
t r n D\end{array}$ \\
\hline $\begin{array}{l}\text { Elatine } \\
\text { alsinastrum L. }\end{array}$ & $\begin{array}{l}\text { Hungary: } \\
\text { Tiszalúc }\end{array}$ & $\begin{array}{l}48.0 \\
3\end{array}$ & 21.11 & $\begin{array}{l}\text { E. alsinastrum } \\
\text { (HU) }\end{array}$ & $\begin{array}{c}\text { KX55557 } \\
2\end{array}$ & $\begin{array}{c}\text { KX81814 } \\
3\end{array}$ & $\begin{array}{c}\mathrm{KX} 81817 \\
0\end{array}$ & $\begin{array}{c}\mathrm{KX} 81811 \\
6\end{array}$ \\
\hline $\begin{array}{l}\text { E. ambigua } \\
\text { Wight }\end{array}$ & $\begin{array}{l}\text { Italy: } \\
\text { Vigevano }\end{array}$ & $\begin{array}{l}45.3 \\
3\end{array}$ & 8.79 & $\begin{array}{l}\text { E. ambigua } \\
\text { (IT) }\end{array}$ & $\begin{array}{c}\text { KX55557 } \\
3\end{array}$ & $\begin{array}{c}\text { KX81815 } \\
0\end{array}$ & $\begin{array}{c}\mathrm{KX} 81817 \\
7\end{array}$ & $\begin{array}{c}\text { KX81812 } \\
3\end{array}$ \\
\hline $\begin{array}{l}\text { E. ambigua } \\
\text { Wight }\end{array}$ & $\begin{array}{l}\text { Nepal: } \\
\text { Aardash } \\
\text { Nagar }\end{array}$ & $\begin{array}{l}27.0 \\
1\end{array}$ & 84.86 & $\begin{array}{l}\text { E. ambigua } \\
\text { (NP) }\end{array}$ & $\begin{array}{c}\text { KX55557 } \\
4\end{array}$ & $\begin{array}{c}\text { KX81815 } \\
1\end{array}$ & $\begin{array}{c}\text { KX81817 } \\
8\end{array}$ & $\begin{array}{c}\mathrm{KX} 81812 \\
4\end{array}$ \\
\hline $\begin{array}{l}\text { E. } \\
\text { brachysperma } \\
\text { A.Gray }\end{array}$ & $\begin{array}{l}\text { USA, } \\
\text { California: } \\
\text { Fallbrook }\end{array}$ & $\begin{array}{l}33.4 \\
6\end{array}$ & $\begin{array}{l}-\begin{array}{l}- \\
117.3 \\
7\end{array} \\
\end{array}$ & $\begin{array}{l}\text { E. } \\
\text { brachysperma } \\
\text { (US) }\end{array}$ & $\begin{array}{c}\text { KX55557 } \\
5\end{array}$ & $\begin{array}{c}\text { KX81814 } \\
6\end{array}$ & $\begin{array}{c}\text { KX81817 } \\
3\end{array}$ & $\begin{array}{c}\text { KX81811 } \\
9\end{array}$ \\
\hline $\begin{array}{l}\text { E. brochonii } \\
\text { Clav. }\end{array}$ & $\begin{array}{l}\text { Morocco: } \\
\text { Ben } \\
\text { Slimane }\end{array}$ & $\begin{array}{l}33.6 \\
2\end{array}$ & -7.07 & $\begin{array}{l}\text { E. brochonii } \\
\text { (MA) }\end{array}$ & $\begin{array}{c}\text { KX55557 } \\
6\end{array}$ & $\begin{array}{c}\text { KX81814 } \\
4\end{array}$ & $\begin{array}{c}\text { KX81817 } \\
1\end{array}$ & $\begin{array}{c}\text { KX81811 } \\
7\end{array}$ \\
\hline $\begin{array}{l}\text { E. brochonii } \\
\text { Clav. }\end{array}$ & $\begin{array}{l}\text { Spain: San } \\
\text { Silvestre de } \\
\text { Guzmán }\end{array}$ & 37.4 & -7.36 & $\begin{array}{l}\text { E. brochonii } \\
\text { (SP) }\end{array}$ & $\begin{array}{c}\text { KX55557 } \\
7\end{array}$ & $\begin{array}{c}\text { KX81814 } \\
5\end{array}$ & $\begin{array}{c}\text { KX81817 } \\
2\end{array}$ & $\begin{array}{c}\text { KX81811 } \\
8\end{array}$ \\
\hline $\begin{array}{l}\text { E. californica } \\
\text { A.Gray }\end{array}$ & $\begin{array}{l}\text { USA, } \\
\text { California: } \\
\text { Los } \\
\text { Angeles }\end{array}$ & $\begin{array}{l}33.8 \\
2\end{array}$ & $\begin{array}{l}- \\
118.3 \\
4\end{array}$ & $\begin{array}{l}\text { E. californica } \\
\text { (US) }\end{array}$ & $\begin{array}{c}\text { KX55557 } \\
8\end{array}$ & $\begin{array}{c}\text { KX81815 } \\
4\end{array}$ & $\begin{array}{c}\text { KX81818 } \\
1\end{array}$ & $\begin{array}{c}\mathrm{KX} 81812 \\
7\end{array}$ \\
\hline $\begin{array}{l}\text { E. } \\
\text { campylosperm } \\
\text { a Seub. ex } \\
\text { Walp. }\end{array}$ & $\begin{array}{l}\text { Italy: } \\
\text { Sardinia: } \\
\text { Gesturi }\end{array}$ & $\begin{array}{l}39.7 \\
3\end{array}$ & 9.03 & $\begin{array}{l}E . \\
\text { campylosperm } \\
a(\mathrm{IT})\end{array}$ & $\begin{array}{c}\text { KX55557 } \\
9\end{array}$ & $\begin{array}{c}\text { KX81816 } \\
0\end{array}$ & $\begin{array}{c}\text { KX81818 } \\
7\end{array}$ & $\begin{array}{c}\text { KX81813 } \\
3\end{array}$ \\
\hline $\begin{array}{l}\text { E. } \\
\text { campylosperm } \\
\text { a Seub. ex } \\
\text { Walp. }\end{array}$ & $\begin{array}{l}\text { Spain: El } \\
\text { Rocío }\end{array}$ & $\begin{array}{l}37.1 \\
2\end{array}$ & -6.49 & $\begin{array}{l}E . \\
\text { campylosperm } \\
a(\mathrm{SP})\end{array}$ & $\begin{array}{c}\text { KX55558 } \\
0\end{array}$ & $\begin{array}{c}\text { KX81816 } \\
1\end{array}$ & $\begin{array}{c}\text { KX81818 } \\
8\end{array}$ & $\begin{array}{c}\text { KX81813 } \\
4\end{array}$ \\
\hline E. gussonei & Morocco: & 33.6 & -7.1 & E. gussonei & $\begin{array}{c}\text { KX55558 } \\
1\end{array}$ & $\begin{array}{c}\text { KX81816 } \\
3\end{array}$ & $\begin{array}{c}\mathrm{KX} 81819 \\
0\end{array}$ & $\begin{array}{c}\text { KX81813 } \\
6\end{array}$ \\
\hline
\end{tabular}




\begin{tabular}{|c|c|c|c|c|c|c|c|c|}
\hline $\begin{array}{l}\text { (Sommier) } \\
\text { Brullo et al.. }\end{array}$ & $\begin{array}{l}\text { Ben } \\
\text { Slimane }\end{array}$ & 1 & & (MA) & & & & \\
\hline $\begin{array}{l}\text { E. gussonei } \\
\text { (Sommier) } \\
\text { Brullo et al. }\end{array}$ & $\begin{array}{l}\text { Spain: } \\
\text { Casar de } \\
\text { Cáceres }\end{array}$ & $\begin{array}{l}39.3 \\
3\end{array}$ & -6.25 & $\begin{array}{l}\text { E. gussonei } \\
\text { (SP) }\end{array}$ & $\begin{array}{c}\text { KX55558 } \\
2\end{array}$ & $\begin{array}{c}\text { KX81816 } \\
8\end{array}$ & $\begin{array}{c}\text { KX81819 } \\
5\end{array}$ & $\begin{array}{c}\text { KX81814 } \\
1\end{array}$ \\
\hline $\begin{array}{l}\text { E. gussonei } \\
\text { (Sommier) } \\
\text { Brullo et al. }\end{array}$ & $\begin{array}{l}\text { Malta: } \\
\text { Gózó: Ta' } \\
\text { Sannat }\end{array}$ & $\begin{array}{l}36.0 \\
1\end{array}$ & 14.25 & $\begin{array}{l}\text { E. gussonei } \\
\text { (MT) }\end{array}$ & $\begin{array}{c}\text { KX55558 } \\
3\end{array}$ & $\begin{array}{c}\text { KX81816 } \\
4\end{array}$ & $\begin{array}{c}\text { KX81819 } \\
1\end{array}$ & $\begin{array}{c}\text { KX81813 } \\
7\end{array}$ \\
\hline $\begin{array}{l}\text { E. gussonei } \\
\text { (Sommier) } \\
\text { Brullo et al. }\end{array}$ & $\begin{array}{l}\text { Italy: } \\
\text { Lampedusa }\end{array}$ & $\begin{array}{l}35.5 \\
1\end{array}$ & 12.56 & $\begin{array}{l}\text { E. gussonei } \\
\text { (LMP) }\end{array}$ & $\begin{array}{c}\text { KX55558 } \\
4\end{array}$ & $\begin{array}{c}\mathrm{KX} 81816 \\
9\end{array}$ & $\begin{array}{c}\text { KX81819 } \\
6\end{array}$ & $\begin{array}{c}\text { KX81814 } \\
2\end{array}$ \\
\hline $\begin{array}{l}\text { E. gussonei } \\
\text { (Sommier) } \\
\text { Brullo et al. }\end{array}$ & $\begin{array}{l}\text { Italy: } \\
\text { Sicily: } \\
\text { Modica }\end{array}$ & $\begin{array}{l}36.7 \\
6\end{array}$ & 14.77 & $\begin{array}{l}\text { E. gussonei } \\
\text { (IT) }\end{array}$ & $\begin{array}{c}\text { KX55558 } \\
5\end{array}$ & $\begin{array}{c}\mathrm{KX} 81816 \\
2\end{array}$ & $\begin{array}{c}\text { KX81818 } \\
9\end{array}$ & $\begin{array}{c}\mathrm{KX} 81813 \\
5\end{array}$ \\
\hline $\begin{array}{l}\text { E. hexandra } \\
\text { DC. }\end{array}$ & $\begin{array}{l}\text { Spain: San } \\
\text { Silvestre de } \\
\text { Guzmán }\end{array}$ & 37.4 & -7.36 & $\begin{array}{l}\text { E. hexandra } \\
\text { (SP) }\end{array}$ & $\begin{array}{c}\text { KX55558 } \\
6\end{array}$ & $\begin{array}{c}\text { KX81814 } \\
8\end{array}$ & $\begin{array}{c}\text { KX81817 } \\
5\end{array}$ & $\begin{array}{c}\text { KX81812 } \\
1\end{array}$ \\
\hline $\begin{array}{l}\text { E. hexandra } \\
\text { DC. }\end{array}$ & $\begin{array}{l}\text { Poland: } \\
\text { Parowa }\end{array}$ & $\begin{array}{l}51.3 \\
9\end{array}$ & 15.23 & $\begin{array}{l}\text { E. hexandra } \\
\text { (PL1) }\end{array}$ & $\begin{array}{c}\text { KX55558 } \\
7\end{array}$ & $\begin{array}{c}\text { Not } \\
\text { included }\end{array}$ & $\begin{array}{c}\text { Not } \\
\text { included }\end{array}$ & $\begin{array}{c}\text { Not } \\
\text { included }\end{array}$ \\
\hline $\begin{array}{l}\text { E. hexandra } \\
\text { DC. }\end{array}$ & $\begin{array}{l}\text { Poland: } \\
\text { Poznań } \\
\text { (Milicz) }\end{array}$ & $\begin{array}{l}51.5 \\
5\end{array}$ & 17.35 & $\begin{array}{l}\text { E. hexandra } \\
\text { (PL2) }\end{array}$ & $\begin{array}{c}\text { KX55558 } \\
8\end{array}$ & $\begin{array}{c}\text { KX81814 } \\
7\end{array}$ & $\begin{array}{c}\text { KX81817 } \\
4\end{array}$ & $\begin{array}{c}\mathrm{KX} 81812 \\
0\end{array}$ \\
\hline $\begin{array}{l}\text { E. hexandra } \\
\text { DC. }\end{array}$ & $\begin{array}{l}\text { UK: } \\
\text { Cornwall, } \\
\text { Bodmin } \\
\text { Moor }^{1}\end{array}$ & NA & NA & $\begin{array}{l}\text { E. hexandra } \\
\text { (GB) }\end{array}$ & $\begin{array}{c}\text { KX55558 } \\
9\end{array}$ & $\begin{array}{c}\text { KX81814 } \\
9\end{array}$ & $\begin{array}{c}\text { KX81817 } \\
6\end{array}$ & $\begin{array}{c}\text { KX81812 } \\
2\end{array}$ \\
\hline $\begin{array}{l}\text { E. hungarica } \\
\text { Moesz }\end{array}$ & $\begin{array}{l}\text { Hungary: } \\
\text { Konyár }\end{array}$ & $\begin{array}{l}47.3 \\
1\end{array}$ & 21.67 & $\begin{array}{l}\text { E. hungarica } \\
\text { (HU) }\end{array}$ & $\begin{array}{c}\text { KX55559 } \\
0\end{array}$ & $\begin{array}{c}\text { KX81815 } \\
5\end{array}$ & $\begin{array}{c}\text { KX81818 } \\
2\end{array}$ & $\begin{array}{c}\text { KX81812 } \\
8\end{array}$ \\
\hline $\begin{array}{l}\text { E. hungarica } \\
\text { Moesz }\end{array}$ & $\begin{array}{l}\text { Russia: } \\
\text { Volgograd }\end{array}$ & $\begin{array}{l}49.7 \\
6\end{array}$ & 45.7 & $\begin{array}{l}\text { E. hungarica } \\
\text { (RU) }\end{array}$ & $\begin{array}{c}\text { KX55559 } \\
1\end{array}$ & $\begin{array}{c}\text { KX81815 } \\
6\end{array}$ & $\begin{array}{c}\text { KX81818 } \\
3\end{array}$ & $\begin{array}{c}\text { KX81812 } \\
9\end{array}$ \\
\hline $\begin{array}{l}\text { E. hydropiper } \\
\text { L. }\end{array}$ & $\begin{array}{l}\text { Hungary: } \\
\text { Tiszagyend } \\
\text { a }\end{array}$ & $\begin{array}{l}47.3 \\
6\end{array}$ & 20.52 & $\begin{array}{l}\text { E. hydropiper } \\
\text { (HU) }\end{array}$ & $\begin{array}{c}\text { KX55559 } \\
2\end{array}$ & $\begin{array}{c}\text { KX81815 } \\
7\end{array}$ & $\begin{array}{c}\text { KX81818 } \\
4\end{array}$ & $\begin{array}{c}\text { KX81813 } \\
0\end{array}$ \\
\hline $\begin{array}{l}\text { E. hydropiper } \\
\text { L. }\end{array}$ & $\begin{array}{l}\text { Poland: } \\
\text { Kwiecko }\end{array}$ & $\begin{array}{l}54.0 \\
3\end{array}$ & 16.69 & $\begin{array}{l}\text { E. hydropiper } \\
\text { (PL) }\end{array}$ & $\begin{array}{c}\text { KX55559 } \\
3\end{array}$ & $\begin{array}{c}\text { KX81815 } \\
8\end{array}$ & $\begin{array}{c}\mathrm{KX} 81818 \\
5\end{array}$ & $\begin{array}{c}\mathrm{KX} 81813 \\
1\end{array}$ \\
\hline $\begin{array}{l}\text { E. macropoda } \\
\text { Guss. }\end{array}$ & $\begin{array}{l}\text { Turkey: } \\
\text { Büyükhusu }\end{array}$ & $\begin{array}{l}39.5 \\
1\end{array}$ & 26.38 & $\begin{array}{l}\text { E. macropoda } \\
\text { (TR) }\end{array}$ & $\begin{array}{c}\text { KX55559 } \\
4\end{array}$ & $\begin{array}{c}\text { KX81816 } \\
6\end{array}$ & $\begin{array}{c}\text { KX81819 } \\
3\end{array}$ & $\begin{array}{c}\text { KX81813 } \\
9\end{array}$ \\
\hline
\end{tabular}




\begin{tabular}{|c|c|c|c|c|c|c|c|c|}
\hline & $\mathrm{n}$ & & & & & & & \\
\hline $\begin{array}{l}\text { E. macropoda } \\
\text { Guss. }\end{array}$ & $\begin{array}{l}\text { Spain: } \\
\text { Casar de } \\
\text { Cáceres }\end{array}$ & $\begin{array}{l}39.1 \\
9\end{array}$ & -6.29 & $\begin{array}{l}\text { E. macropoda } \\
\text { (SP) }\end{array}$ & $\begin{array}{c}\text { KX55559 } \\
5\end{array}$ & $\begin{array}{c}\text { KX81816 } \\
5\end{array}$ & $\begin{array}{c}\text { KX81819 } \\
2\end{array}$ & $\begin{array}{c}\mathrm{KX} 81813 \\
8\end{array}$ \\
\hline $\begin{array}{l}\text { E. macropoda } \\
\text { Guss. }\end{array}$ & $\begin{array}{l}\text { Italy: } \\
\text { Sardegna: } \\
\text { Olmedo }\end{array}$ & $\begin{array}{l}40.6 \\
3\end{array}$ & 8.41 & $\begin{array}{l}\text { E. macropoda } \\
\text { (IT) }\end{array}$ & $\begin{array}{c}\text { KX55559 } \\
6\end{array}$ & $\begin{array}{c}\text { KX81816 } \\
7\end{array}$ & $\begin{array}{c}\text { KX81819 } \\
4\end{array}$ & $\begin{array}{c}\text { KX81814 } \\
0\end{array}$ \\
\hline $\begin{array}{l}\text { E. } \\
\text { orthosperma } \\
\text { Dueb. }\end{array}$ & $\begin{array}{l}\text { Finland: } \\
\text { Oulu }\end{array}$ & $\begin{array}{l}65.0 \\
6\end{array}$ & 25.47 & $\begin{array}{l}E . \\
\text { orthosperma } \\
\text { (FI) }\end{array}$ & $\begin{array}{c}\text { KX55559 } \\
7\end{array}$ & $\begin{array}{c}\text { KX81815 } \\
9\end{array}$ & $\begin{array}{c}\text { KX81818 } \\
6\end{array}$ & $\begin{array}{c}\text { KX81813 } \\
2\end{array}$ \\
\hline $\begin{array}{l}\text { E. triandra } \\
\text { Schkuhr }\end{array}$ & $\begin{array}{l}\text { Poland: } \\
\text { Janików }\end{array}$ & $\begin{array}{l}51.5 \\
6\end{array}$ & 14.98 & $\begin{array}{l}\text { E. triandra } \\
\text { (PL) }\end{array}$ & $\begin{array}{c}\text { KX55559 } \\
8\end{array}$ & $\begin{array}{c}\text { KX81815 } \\
3\end{array}$ & $\begin{array}{c}\text { KX81818 } \\
0\end{array}$ & $\begin{array}{c}\text { KX81812 } \\
6\end{array}$ \\
\hline $\begin{array}{l}\text { E. triandra } \\
\text { Schkuhr }\end{array}$ & $\begin{array}{l}\text { Hungary: } \\
\text { Karcag }\end{array}$ & $\begin{array}{l}47.2 \\
7\end{array}$ & 20.9 & $\begin{array}{l}\text { E. triandra } \\
(\mathrm{HU})\end{array}$ & $\begin{array}{c}\text { KX55559 } \\
9\end{array}$ & $\begin{array}{c}\text { KX81815 } \\
2\end{array}$ & $\begin{array}{c}\text { KX81817 } \\
9\end{array}$ & $\begin{array}{c}\mathrm{KX} 81812 \\
5\end{array}$ \\
\hline $\begin{array}{l}\text { Bergia texana } \\
\text { Seub. ex } \\
\text { Walp. }^{2}\end{array}$ & $\begin{array}{l}\text { USA, } \\
\text { California: } \\
\text { Perris }\end{array}$ & $\begin{array}{l}33.8 \\
4\end{array}$ & $\begin{array}{l}- \\
117.1 \\
3\end{array}$ & Bergia & $\begin{array}{c}\text { KX55560 } \\
0\end{array}$ & $\begin{array}{c}\text { Not } \\
\text { included }\end{array}$ & $\begin{array}{c}\text { Not } \\
\text { included }\end{array}$ & $\begin{array}{c}\text { Not } \\
\text { included }\end{array}$ \\
\hline
\end{tabular}

\footnotetext{
${ }^{1}$ purchased from Kew DNA Bank (ID: 12361); ${ }^{2}$ included as outgroup
} 
725
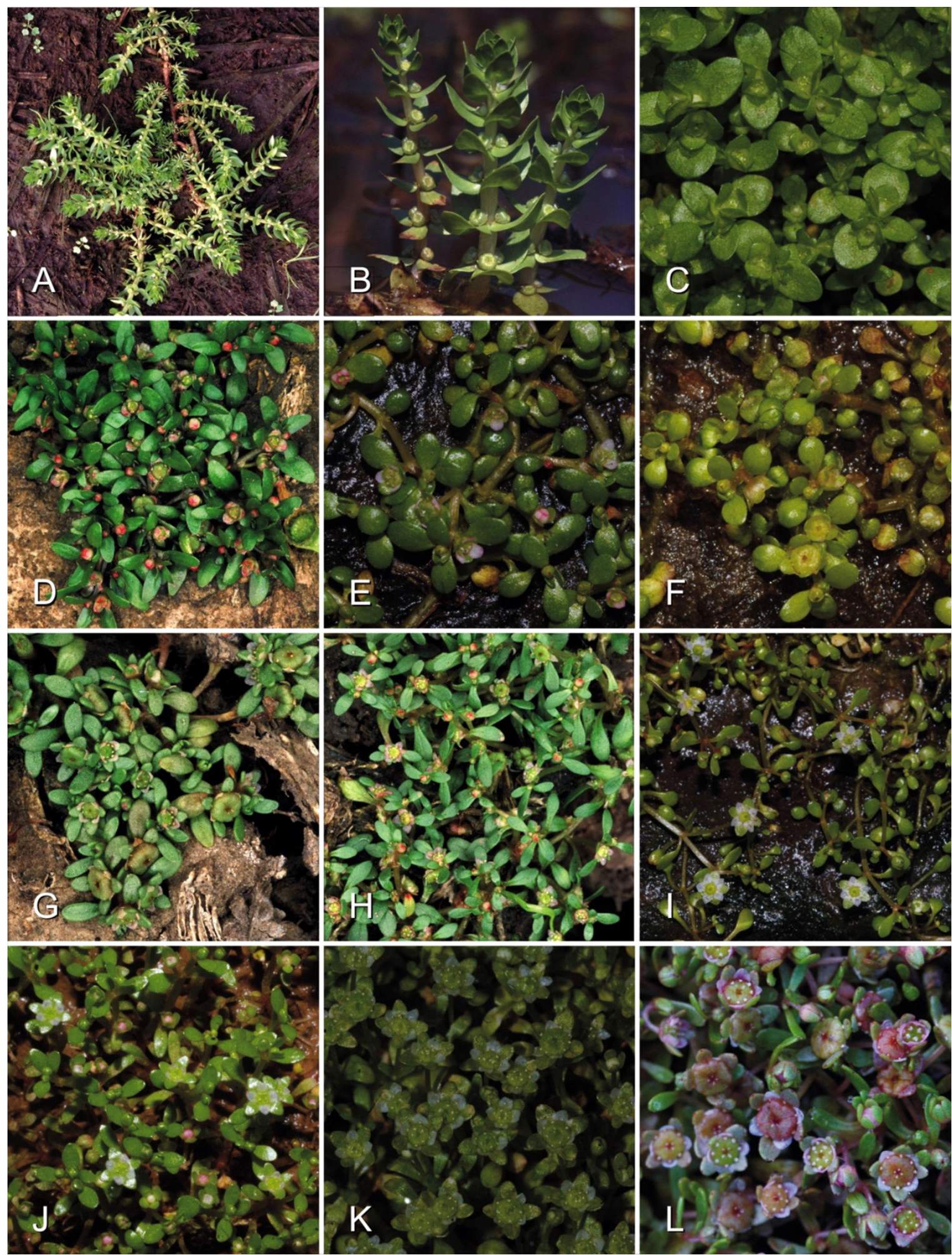

726

728

Fig. 1. Examples of morphological diversity in the genus Elatine. A, habit of the terrestrial form

729 of Elatine alsinastrum (E. subgenus Potamopithys); B, flowering shoots of water-living form of

730 Elatine alsinastrum; C, E. brochonii (Spain); D, E. triandra (Hungary); E, E. hexandra (Poland); 
731 F, E. californica (USA); G, E. hungarica (Hungary); H, E. hydropiper (Hungary); I, E.

732 campylosperma (Spain); J, E. gussonei (Lampedusa); K, E. gussonei (Sicily); K, E. macropoda

733 (Sardinia). — Photographs by A. Molnár V. 
734

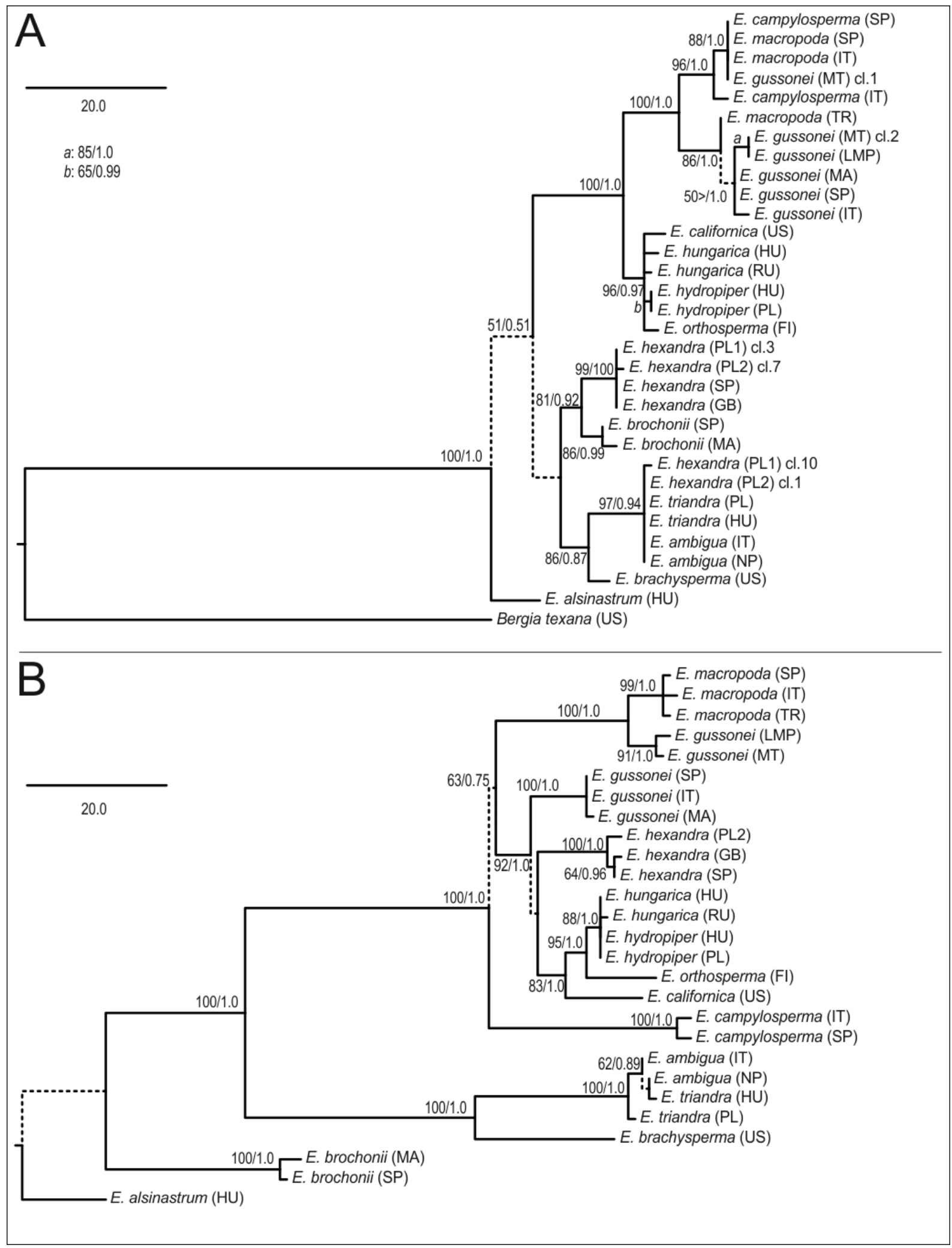


736 Fig. 2. Phylogenetic trees reconstructed using the nrITS (A) and plastid (B) matrices. Both trees 737 are arbitrary chosen MPTs displayed as phylograms with bootstrap support percentages /

738 posterior probability values at the corresponding branches. Dash indicates lack of statistical

739 support, and such branches are indicated by dashed lines. A scale bar representing 20 mutational

740 changes is displayed on both trees, and the abbreviation 'cl.' denotes cloned nrITS sequences on 741 the nrITS tree. 


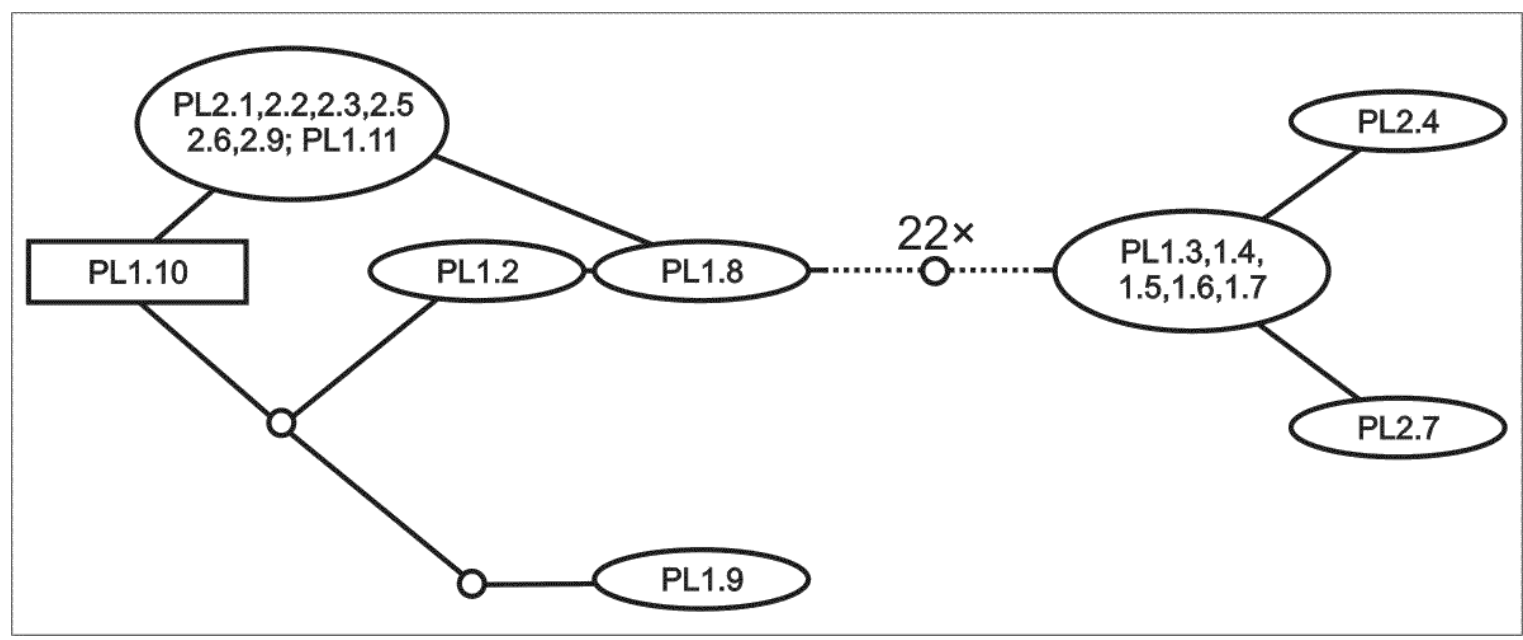

Fig. 3. TCS-network of cloned nrITS sequences of Polish E. hexandra accessions. Clone names follow the abbreviated sample name, while the number following it is the indetifier of the clone

747 sequenced. Hypothetical (unrecovered) ribotypes are represented by small circles, and the 22

748 such ribotypes separating the two ribotype-groups are not represented to keep the figure easily 749 readable. 


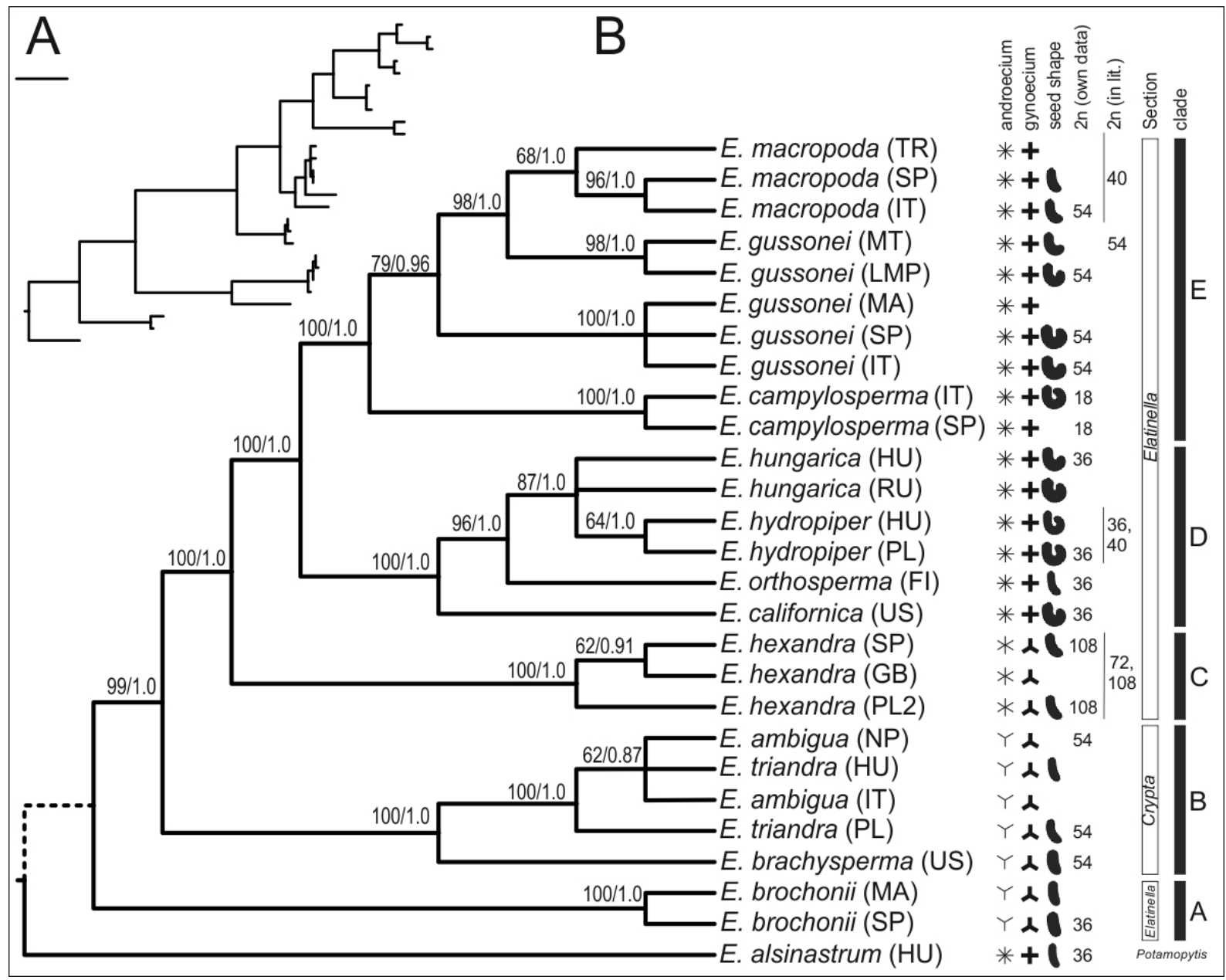

Fig. 4. One of the two MPTs resulted from MP analysis of the combined (nrITS+plastid accD-

753 psaI, psbJ-petA, ycf6-psbM-trnD) sequences displayed as a phylogram (A) and as a cladogram

754 (B). Next to each branch are bootstrap support values resulting from 1,000 pseudo-replicate

755 followed by Bayesian PP values after the slash. 


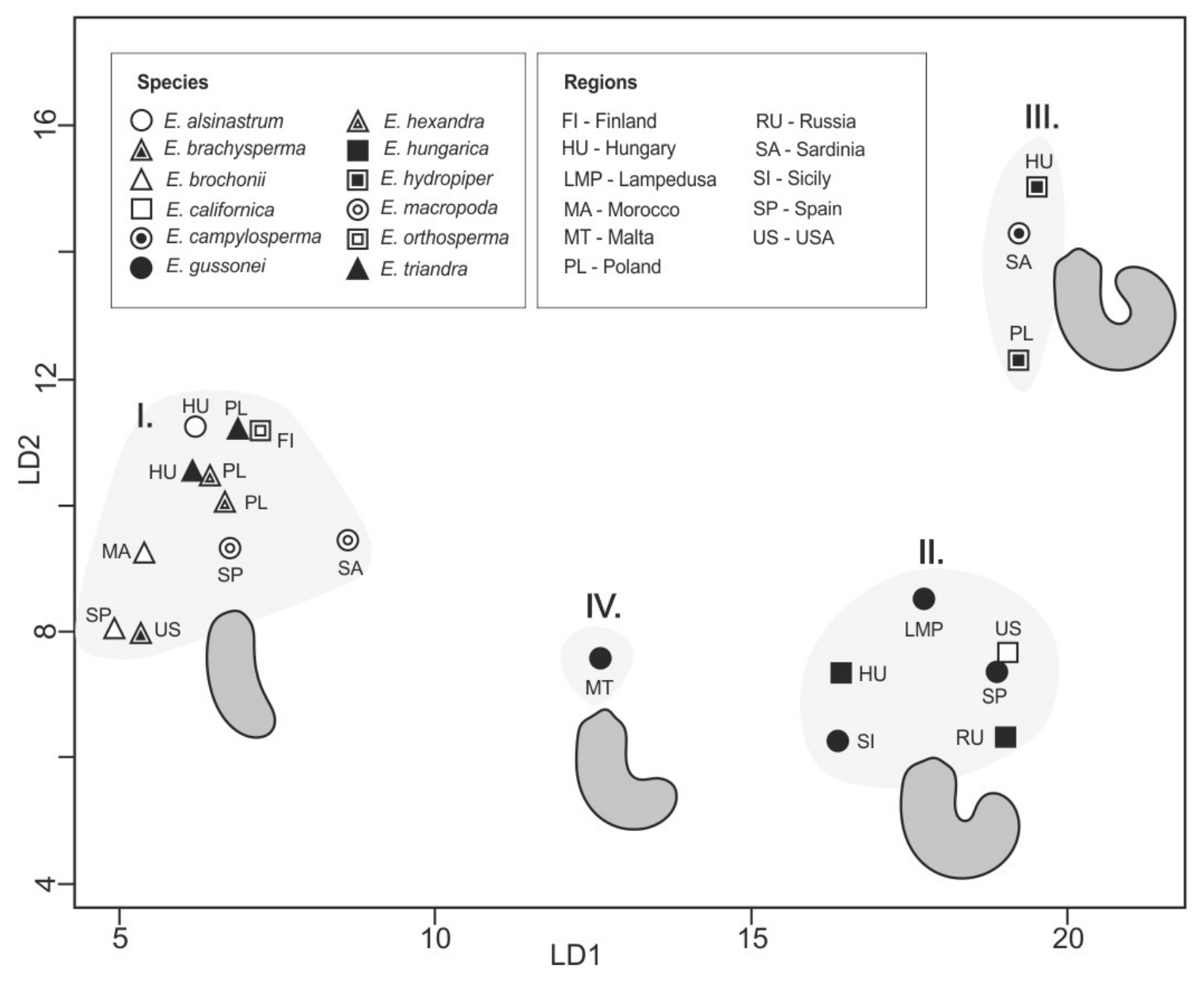

757 Fig. 5. CVA scatter plot of seed outlines. Average outlines are presented. 